Research Article

\title{
Evaluation of antimicrobial activity of orange peel extract against oral biofilm forming organisms: an in vitro microbial study and scanning electron microscopic assessment
}

\author{
Chetana Dilip Mankar ${ }^{1}$, Mona Udayan Shah ${ }^{1}$, Yogesh Sharad Doshi ${ }^{1}$, Monika Bajaj ${ }^{1}$, Vidhi \\ Kevadia $^{3}$, Roshini Vinod ${ }^{2}$
}

\begin{abstract}
${ }^{1}$ Department of Periodontology, ${ }^{2}$ Department of Oral Pathology and Microbiology, Pandit Deendayal Upadhyay Dental College and Hospital, Solapur, Maharashtra, India

${ }^{3}$ Department of Periodontology, KLE Dental College and Hospital, Belgaum, Karnataka, India
\end{abstract}

Received: 21 June 2016 Accepted: 05 August 2016

*Correspondence to:

Dr. Chetana Dilip Mankar, Email: drcdmankar@gmail.com

Copyright: (C) the author(s), publisher and licensee Medip Academy. This is an openaccess article distributed under the terms of the Creative Commons Attribution NonCommercial License, which permits unrestricted noncommercial use, distribution, and reproduction in any medium, provided the original work is properly cited.

\begin{abstract}
Background: To evaluate in vitro antimicrobial activity of orange peel extract, $0.2 \%$ chlorhexidine $(\mathrm{CHX})$ and saline against dental biofilm-forming bacteria and their effect on plaque structure under SEM.

Methods: Present study included 3 groups; Group A: Orange peel extract; Group B: $0.2 \%$ CHX and Group C: Saline. MIC of each group was determined by broth and well diffusion method. Reference strains of Porphyromonas gingivalis (P.g.), Prevotella intermedia (P.i.) and Aggregatibacter actinomycetemcomitans (A.a.) were selected as being colonizers in dental biofilm. For SEM analysis, plaque retained orthodontic e-chains were subjected to each group for 60s and studied under SEM.

Results: The MIC of Group A by broth diffusion method is $66.66 \mu \mathrm{g} / \mathrm{ml}$ for $P$. intermedia, $75 \mu \mathrm{g} / \mathrm{ml}$ for $P$. gingivalis and $33.33 \mu \mathrm{g} / \mathrm{ml}$ for A.a. MIC of Group B was $14.58 \mu \mathrm{g} / \mathrm{ml}$ for P.i., $7.29 \mu \mathrm{g} / \mathrm{ml}$ for P.g. and $20.83 \mu \mathrm{g} / \mathrm{ml}$ for A.a. MIC of Group C was $83.33 \mu \mathrm{g} / \mathrm{ml}$ for $A . a$. while P.i. and P.g. showed resistance to Group C. The determination of MIC by well diffusion showed increase in clear zone diameter with increasing concentrations. Greater zone of inhibition was seen in Group B with statistical significance for all 3 microorganisms. Morphologic changes in the SEM study showed maximum change in the surface characteristics and loss of adhesion of the clusters of microorganisms subjected to Group B.

Conclusions: $\mathrm{CHX}$ and orange peel extract exhibited notable anti-microbial activity against biofilm organisms, but at varying concentrations. The plaque samples subjected to orange peel extract showed slightly shrunken and coarse form indicating its ability to disrupt the plaque biofilm.
\end{abstract}

Keywords: Orange peel extract, Chlorhexidine, Saline, Well diffusion, Broth diffusion, Scanning electron microscope

\section{INTRODUCTION}

Humans are in an intimate and dynamic relationship with microorganisms present in all the environmentally exposed surfaces of the body as well as those that cause disease. These microbes viz. viruses, mycoplasma, bacteria, fungi and protozoa colonize the mucosal and dental surfaces in the oral cavity to form multidimensional, structurally organized multispecies communities termed as biofilms. The biofilm formed on teeth is called as dental plaque which is responsible for inflammatory diseases of periodontium i.e. gingivitis and periodontitis. ${ }^{1}$
There is a plethora of information regarding the prevention and the treatment of plaque induced gingivitis and periodontitis. The use of chemical plaque control agents to control plaque and gingivitis levels has been widely evaluated and efficacy for some formulations has been observed in different systematic reviews. ${ }^{2-10}$

Out of a number of chemical plaque control agents available, chlorhexidine is considered as a gold standard. ${ }^{11}$ Though it obeys many features of the ideal chemical agent for plaque control, there are many limitations regarding the safety of its usage over extended periods. $^{12}$ 
Herbal medicines are 'naturally occurring' active ingredients which offer a gentle and enduring way to restore health by the most trustworthy and least harmful way. ${ }^{13}$ Herbal medicine is both promotive and preventive in its approach. ${ }^{14}$ Naturals herbs like triphala, tulsi patra, green tea, neem, clove oil, pudina, aloe vera, pomegranate, cinnamon and many more used either as a whole single herb or in combination have been scientifically proven to be safe and effective medicine against various oral health problems like bleeding gums, halitosis, mouth ulcers and preventing tooth decay. ${ }^{15-22}$

Orange, a tangy juicy fruit, belongs to family Rutaceae is scientifically known as Citrus reticulata and has a gross production of around 120 million tons. The peel of Citrus reticulata is used in various skin and stomach ailments, cancer, as a diuretic, carminative and immuno-enhancing agent. It is also used to treat and prevent vitamin deficiencies, colds, flu, scurvy and helps to fight against bacterial and viral infections. Various studies reported its potent antibacterial activity against Pseudomonas aeruginosa, Staphylococcus aureus, Staphylococcus epidermidis, Shigella flexineri, Bacillus subtilis, Escherichia coli and Klebsiella pneumonia. ${ }^{23}$

Recycling of fruit waste is one of the most important ways of utilizing it in a number of novel products which are essentially required for human, animal and plant nutrition as well as in the pharmaceutical industry. ${ }^{23}$ Thorough literature search revealed very few studies investigating the effect of orange peel extract on oral disease pathogens. This study was thus undertaken to evaluate the antimicrobial action of orange peel extract against the periopathogens present in dental plaque.

Hence, the objective of the present study was in vitro evaluation of the antimicrobial effect of orange peel extract, chlorhexidine and saline against periopathogens by determining minimum inhibitory concentration (MIC). The present study also included the SEM analysis of the effect of orange peel extract on plaque structure in comparison with chlorhexidine and saline.

\section{METHODS}

The study was conducted in the department of microbiology and immunology in NGH Maratha Mandal Institute of Dental Sciences and Research Centre, Belgaum, Karnataka. The SEM study was conducted in ICON Analytical Laboratory, Worli, Mumbai.

This study was conducted on three different organisms and three different mouthwashes.

Reference strains of Porphyromonas gingivalis ATCC 3327, Prevotella intermedia ATCC 2564 and Aggregatibacter actinomycetemcomitans ATCC 33384 were selected as being colonizers in dental biofilm formation. These strains were obtained from Institute of Microbial Technology, Chandigarh.

\section{Preparation of orange peel aqueous extract}

Mature fruits of Nagpur oranges of mandarin variety (Citrus reticulata) were used as source of peel. The peels were dried in a tray drier for $24 \mathrm{hrs}$ at $60^{\circ} \mathrm{c}$. The dried peels were ground with the help of hammer mill/grinder. Distilled water at room temperature was used as a solvent. The mixture of solvent and peel powder was subjected to extraction temperature of $40^{\circ} \mathrm{C}$ for $4 \mathrm{hrs}$ in a water bath. The liquid extract was separated from solids by filtration through Whatman No. 1 filter paper and was sterilized in an autoclave. The aqueous extract was stored at $-20^{\circ} \mathrm{C}$ until used for further studies. ${ }^{24}$

The mouthwashes were divided into three groups:

1. Group A - Orange peel aqueous extract.

2. Group B - Chlorhexidine mouthwash (0.2\% CHX) marketed by ICPA Health Care Ltd.

3. Group C - Saline $(0.9 \%$ w/v) marketed by Fresenius Kabi India Pvt. Ltd.

\section{Determination of minimum inhibitory concentration by broth diffusion method}

MIC is the smallest range of product dilution capable of preventing bacterial growth with formation of inhibition zones measured in millimeters with a digital caliper. All tests were performed in triplicates. For this procedure, 9 dilutions of Group A, Group B and Group C were done with brain heart infusion (BHI) broth microdilution assay. In the initial tube $20 \mu 1$ of Group A was added into $380 \mu 1$ of BHI broth. For dilutions $200 \mu \mathrm{l}$ of BHI broth was added into the next 9 tubes separately. Then from the initial tube, $200 \mu \mathrm{l}$ was transferred to the first tube containing $200 \mu \mathrm{l}$ of BHI broth. This was considered as $10^{-1}$ dilution. From $10^{-1}$ diluted tube $200 \mu \mathrm{l}$ was transferred to second tube to make $10^{-2}$ dilution. The serial dilution was repeated up to $10^{-9}$ dilution for each drug. From the maintained stock cultures of required organisms, $5 \mu \mathrm{l}$ was taken and added into $2 \mathrm{ml}$ of BHI broth. In each serially diluted tube, $200 \mu$ l of above culture suspension was added. Test was done on 100 $\mu \mathrm{g} / \mathrm{ml}, 50 \mu \mathrm{g} / \mathrm{ml}, 25 \mu \mathrm{g} / \mathrm{ml}, 12.5 \mu \mathrm{g} / \mathrm{ml}, 6.25 \mu \mathrm{g} / \mathrm{ml}, 3.12$ $\mu \mathrm{g} / \mathrm{ml}, 1.6 \mu \mathrm{g} / \mathrm{ml}, 0.8 \mu \mathrm{g} / \mathrm{ml}, 0.4 \mu \mathrm{g} / \mathrm{ml}$ and $0.2 \mu \mathrm{g} / \mathrm{ml}$ dilutions of Group A, Group B and Group C. The tubes were incubated at $37^{\circ} \mathrm{C}$ for $48-72$ hours in an anaerobic jar and observed for turbidity. ${ }^{25}$ Each group was tested three times.

\section{Screening for antimicrobial activity by well diffusion method}

The purpose of well diffusion test is to determine the sensitivity or resistance of microorganisms to various antimicrobial compounds. The pathogenic organism is grown on a specific medium in which wells of specific diameter are made and the antimicrobial agent is added to these wells. The presence of clear zone around the wells 
is an indirect measure of the ability of that compound to inhibit that organism. ${ }^{26}$

The media used in this study were blood agar for $P$. gingivalis, kanamycin blood agar for $P$. intermedia and dentaid medium for A. actinomycetemcomitans. Each media was inoculated with respective micro-organism by lawn culture method.

The aqueous extracts of the Group A, Group B and Group $\mathrm{C}$ were used for the antimicrobial screening using the agar well diffusion method. The cultured media was punched with $6 \mathrm{~mm}$ diameter wells which were filled with various concentrations of $75 \mu \mathrm{l}, 50 \mu \mathrm{l}, 25 \mu \mathrm{l}, 10 \mu \mathrm{l}$ and $5 \mu$ l of Group A, Group B and Group C. The plates were then incubated at $37^{\circ} \mathrm{C}$ for 24 hours. After incubation, the diameter of zone of inhibition for each extract was measured in millimeters as its diameter between the edges of the lawn. Each group was tested three times.

For SEM analysis, plaque samples were collected from echains of patients undergoing orthodontic treatment visiting the department of orthodontics in PDU Dental College, Solapur, India. The e-chains were then stored in vials containing reduced transfer fluid (RTF) and transferred to laboratory. The e-chains were exposed to $10 \mathrm{ml}$ Group A, Group B and Group C in sterile petri dishes for 60 seconds.
These samples were dried, glued on the stubs and were subjected to golden sputtering. Once cooled, they were stored in a vacuum sealed glass container and were observed under SEM.

The data obtained was analyzed using SPSS version 16.0 (SPSS Inc., Chicago, Illinois, USA). Descriptive statistics such as mean and SD along with comparison in diameter of mean zone of inhibition within and between groups were performed using One way analysis of variance (ANOVA) with bonferroni post hoc for three organisms. Confidence level and level of significance were set at $95 \%$ and $5 \%$ respectively. A p-value less than 0.05 was considered as significant.

\section{RESULTS}

The mean diameter of zone of inhibition for all groups for $P$. intermedia, P.gingivalis and A.actinomycetemcomitans respectively in as shown in Table 1, 2 and 3. The mean MIC values of all groups by broth diffusion method are shown in Table 4.

The mean zone of inhibition for $P$. intermedia increased significantly with increasing concentration for all the three groups with Group B showing greatest zone of inhibition with statistically significant differences with Group A and Group C. Group C did not show any clear zone $\leq 25 \mu 1$.

Table 1: Mean diameter of zone of inhibition of three groups by well diffusion method for P.intermedia.

\begin{tabular}{|lllllll|l|} 
Groups $(\boldsymbol{\mu l})$ & Concentrations $($ Mean \pm SD) & & & & p \\
& $\mathbf{7 5}$ & $\mathbf{5 0}$ & $\mathbf{2 5}$ & $\mathbf{1 0}$ & $\mathbf{5}$ & 0.000 \\
\hline Group A & $14 \pm 1.0000$ & $11 \pm 1.0000$ & $10 \pm 1.0000$ & $8 \pm 0.0000$ & $8 \pm 0.0000$ & 0.006 \\
\hline Group B & $19 \pm 1.0000$ & $19 \pm 1.0000$ & $17 \pm 1.0000$ & $16 \pm 1.0000$ & $16 \pm 1.0000$ & 0.008 \\
\hline Group C & $14 \pm 1.0000$ & $10 \pm 1.0000$ & $\mathrm{R}$ & $\mathrm{R}$ & $\mathrm{R}$ & 0.002 \\
\hline P & 0.001 & 0.000 & 0.000 & 0.000 & & \\
\hline
\end{tabular}

Table 2: Mean diameter of zone of inhibition of three groups by well diffusion method for P.gingivalis.

\begin{tabular}{|c|c|c|c|c|c|c|}
\hline \multirow{2}{*}{ Groups $(\boldsymbol{\mu l})$} & \multicolumn{5}{|c|}{ Concentrations (Mean \pm SD) } & \multirow[b]{2}{*}{$\mathbf{p}$} \\
\hline & 75 & 50 & 25 & 10 & 5 & \\
\hline Group A & $12.6 \pm 0.5773$ & $12 \pm 1.0000$ & $10.3 \pm 0.5773$ & $\mathrm{R}$ & $\mathrm{R}$ & 0.021 \\
\hline Group B & $15 \pm 1.0000$ & $22 \pm 1.0000$ & $19 \pm 1.0000$ & $19 \pm 1.0000$ & $17 \pm 1.0000$ & 0.000 \\
\hline Group C & $7.3 \pm 1.1547$ & $7 \pm 1.0000$ & $6 \pm 1.0000$ & $\mathrm{R}$ & $\mathrm{R}$ & 0.340 \\
\hline $\mathbf{P}$ & 0.000 & 0.000 & 0.000 & & & \\
\hline
\end{tabular}

Table 3: Mean diameter of zone of inhibition of three groups by well diffusion method for A.actinomycetemcomitans.

\begin{tabular}{|lllllll|} 
Groups $(\boldsymbol{\mu l})$ & Concentrations $($ Mean \pm SD $)$ & & & & P \\
& $\mathbf{7 5}$ & $\mathbf{5 0}$ & $\mathbf{2 5}$ & $\mathbf{1 0}$ & $\mathbf{5}$ & $\mathrm{R}$ \\
\hline Group A & $\mathrm{R}$ & $\mathrm{R}$ & $\mathrm{R}$ & $\mathrm{R}$ & 0.000 \\
\hline Group B & $17 \pm 1.0000$ & $18 \pm 1.0000$ & $14 \pm 1.0000$ & $14 \pm 1.0000$ & $22 \pm 1.0000$ & 0.027 \\
\hline Group C & $12 \pm 1.0000$ & $11 \pm 1.0000$ & $9 \pm 1.0000$ & $\mathrm{R}$ & $\mathrm{R}$ & \\
\hline P & 0.004 & 0.001 & 0.004 & & & \\
\hline
\end{tabular}


Table 4: Determination of MIC by broth diffusion method.

\begin{tabular}{|llll|}
\hline Group $(\mu \mathrm{gg} / \mathrm{ml})$ & P.intermedia & P.gingivalis & A.actinomycetemcomitans \\
\hline Group A & 66.66 & 75 & 33.33 \\
\hline Group B & 14.58 & 7.29 & 20.83 \\
\hline Group C & R & R & 83.33 \\
\hline
\end{tabular}

Similar trend for mean zone of inhibition was observed for $P$. gingivalis also in Group $\mathrm{A}$ and $\mathrm{C}$ which was evident statistically. Group B exhibited maximum zone of inhibition $(22 \pm 1.0 \mathrm{~mm})$ at $50 \mu \mathrm{l}$. However, Group A and Group $\mathrm{C}$ became resistant at and $\leq 10 \mu \mathrm{l}$.

For A. actinomycetemcomitans, the test group i.e. Group A was resistant at all concentrations while Group B showed greater zone of inhibition than Group $C$ with statistically significant differences. MIC of Group A and B were $66.66 \mu \mathrm{g} / \mathrm{ml}$ and $14.58 \mu \mathrm{g} / \mathrm{ml}$ respectively for $\mathrm{P}$. intermedia. The MIC for $P$. gingivalis was $75 \mu \mathrm{g} / \mathrm{ml}$ for Group A and $7.29 \mu \mathrm{g} / \mathrm{ml}$ for Group B P. intermedia and $P$. gingivalis were resistant to Group C. MIC for $A$. actinomycetemcomitans was $33.33 \mu \mathrm{g} / \mathrm{ml}$ in Group A, $20.83 \mu \mathrm{g} / \mathrm{ml}$ in Group B and $83.33 \mu \mathrm{g} / \mathrm{ml}$ in Group C. At any point of time, higher MIC values were recorded for orange peel extract as compared to $0.2 \% \mathrm{CHX}$. The SEM structure of plaque subjected to Group A, Group B and Group $\mathrm{C}$ showed multilayered bacteria embedded in a heavy extracellular matrix. The bacteria in the plaque showed coaggregation with test-tube brush and corncob formation. The SEM structure of Group B showed loss of adhesion of clumps of bacterial cells exposing the rod shaped filaments and cocci as seen in Figure 2.

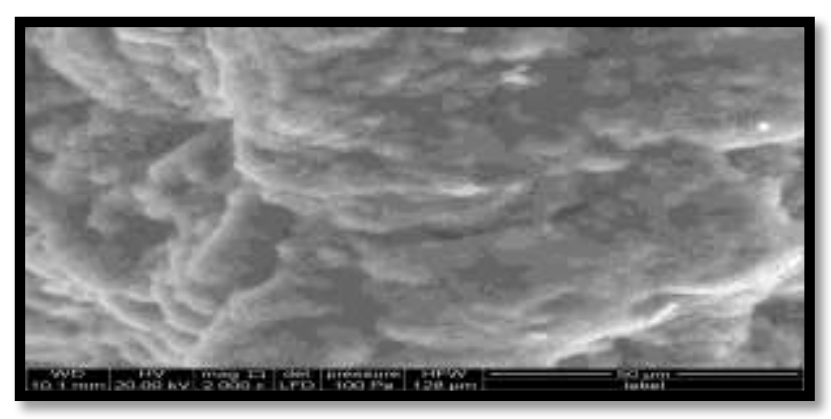

Figure 1: Scanning electron microscopic images of plaque on orthodontic e-chains subjected to Group A.

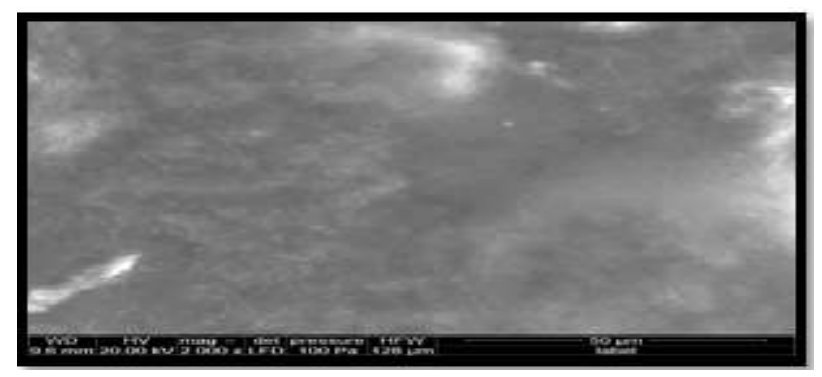

Figure 2: Scanning electron microscopic images of plaque on orthodontic e-chains subjected to Group B.
The surface characteristics of Group A showed slightly shrunken and coarse appearance but no appreciable change in the morphology of bacterial cells as presented in Figure 1. The plaque samples subjected to Group C showed intact cellular structures with coaggregation as in Figure 3.

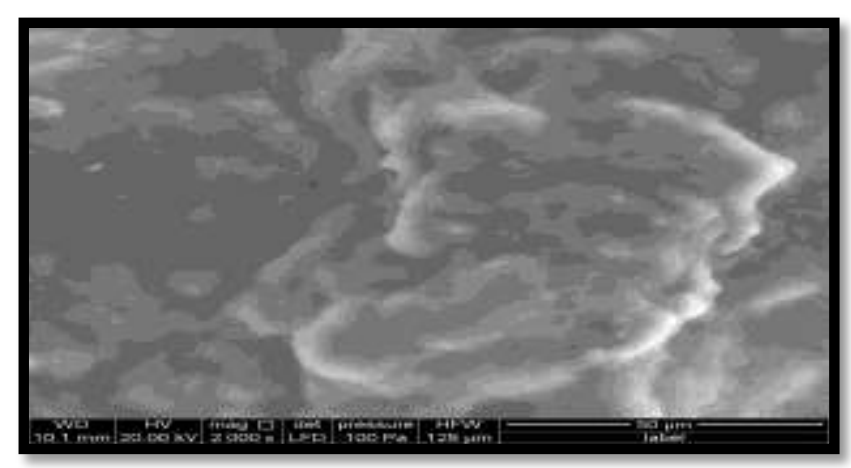

Figure 3: Scanning electron microscopic images of plaque on orthodontic e-chains subjected to Group C.

\section{DISCUSSION}

A wide number of plant extracts possess antimicrobial properties and are used as natural alternatives to treat several diseases. The orange peel extract contains phytochemical constituents like tannins, saponins, flavonoids, terpenoids, cardiac glycosides, alkaloids and phenols. ${ }^{27}$ Tannins form irreversible complexes with proline rich proteins which impede the formation of the biofilm specifically by the early colonizers. ${ }^{28}$ The terpenoids in the ethanolic extract of orange peel are involved in membrane disruption by the lipophilic compounds. $^{29}$

Several studies have investigated the antimicrobial activity of various natural products against oral microorganisms. However, to the best of our knowledge there are no studies comparing the antimicrobial action of orange peel extract, chlorhexidine and saline mouthwashes against oral biofilm forming organisms. Therefore present study was designed to evaluate and compare antimicrobial effect of orange peel extract, chlorhexidine and saline mouthwashes against periopathogens viz. A. actinomycetemcomitans, $P$. gingivalis and $P$. intermedia. Various microorganisms are responsible for causing periodontal inflammation, but we have selected $P$. gingivalis, A. actinomycetemcomitans and $P$. intermedia because they are established periopathogens and are associated with progression, severity and recurrence of periodontal disease. ${ }^{30,31}$ 
The peel of the citrus fruits is an important bye-product of citrus processing industries. A large amount of peel is produced and is considered as waste. A citrus peel contains high quantity of phenolic compounds including several flavonoids. The citrus peel extracts and essential oils are known to exhibit various biological activities such as antimicrobial and antioxidant activities. ${ }^{32}$ Many studies have also shown that the essential oils from citrus spp. have pronounced antimicrobial effect against both bacteria and fungi. ${ }^{33-35}$ In this study antimicrobial activity of orange peel aqueous extract at room temperature was evaluated against various periopathogens.

The zone of inhibition of all extracts against periodontal pathogens in the present study increased significantly with increasing concentration which is in agreement with previous studies. $^{23,36,37}$ Although, saline was used as a negative control, it showed some zone of inhibition for all the bacteria tested in the study. The MIC values of orange peel extract obtained in our study ranged from 33.33 $\mu \mathrm{g} / \mathrm{ml}$ for $A . a, 66.66 \mu \mathrm{g} / \mathrm{ml}$ for $P . i$ and $75 \mu \mathrm{g} / \mathrm{ml}$ for $P . g$. These values are much higher than those reported by Hussain et al against the same organisms i.e. ranging from 12.1-14.7 mg/ml. ${ }^{23}$ The difference in the MIC values may be due to the aqueous nature of the solvent used at room temperature in the present study. As stated by Nisha et al, potency of citrus fruit peel extract is enhanced by the type of solvent used indicating that there are some active ingredients in orange peel which have high antimicrobial effect but which would not be released except when orange fruit peel is used in conjunction with a particular solvent (alcohol, water, acetone, petroleum ether, n-hexane). ${ }^{38}$ Carbohydrates, glycosides and saponins are found only in aqueous extract whereas triterpenoids are revealed only in ethanolic extracts. ${ }^{39}$ This explains the lower MICs obtained in the study of Hussain et al wherein ethanol was used as one of the solvents for their extracts which in turn contained terpenoids responsible for membrane disruption and improved antibacterial potency. ${ }^{29}$ Another explanation for differences is the temperature of the solvent used. Jayaseelan and Jashothan explained the role of temperature of the solvent used. They attributed the better activity of hot extracts to the chemical changes caused by the heat treatment as the resulting biomolecules may be more active than the biomolecules found in the cold ethanolic extracts. ${ }^{39}$

Lakhdar reported strong antibacterial activity of essential oils obtained from species of Citrus aurantium against two virulent serotype-b strains of A, suggesting usefulness of these plant products as potential antimicrobial agents in periodontal diseases. ${ }^{40}$

Chlorhexidine was used as a positive control. In the present study, it exhibited better antimicrobial activity against all three tested periopathogens, both in terms of lower MICs and larger zone of inhibition diameters, establishing itself as gold standard again.
The bacteria in the present study i.e. P.gingivalis and P.intermedia are obligate anaerobes and A. $a$ is a facultative anaerobe which was effectively inhibited by aqueous extract of orange peel. ${ }^{38}$ In the present study, the bacteria in the dental plaque were assessed for their morphological changes after treatment with aqueous extract of orange peel, $0.2 \%$ chlorhexidine and normal saline under SEM. The dental plaque samples were obtained from the e-chains of patients undergoing orthodontic treatment to minimize any potential disruption to the biofilm on the lateral surfaces of the plaque. The plaque samples were dessicated before placing the e-chains under the microscope; therefore the structures in the images will be different from their hydrated state. The plaque was examined under a magnification of $200 \mathrm{X}$ and $500 \mathrm{X}$ and a specific magnification of $1000 \mathrm{X}$ and $2000 \mathrm{X}$. Very few studies have revealed the SEM structure of plaque samples obtained ex vivo. The samples subjected to chlorhexidine showed visible changes in the shapes and structures of the bacteria. Chlorhexidine caused most of the bacteria to shrink and form wrinkled surface. The rough surface is indicative of the ruptured cell wall which then makes the cell content to burst out. In comparison with chlorhexidine, orange peel extract shows minimal disruption in the structure of plaque which is appreciated by the surface characteristics. The plaque samples subjected to saline showed intact corn cob appearance of the clusters of bacteria. The mechanism of action of chlorhexidine is more efficient in disrupting the bacterial cell wall and therefore, the antibacterial properties of chlorhexidine are better as compared to orange peel extract.

Even if not as good as chlorhexidine, orange peel extract has shown some inhibition against the tested organisms. The inconsistencies in our study can be explained on the basis of type and temperature of solvent used with variation in extraction technique and shorter incubation period. Therefore, more studies with essential oils and alcoholic extracts should be considered for future research.

\section{ACKNOWLEDGEMENTS}

Funding: No funding sources

Conflict of interest: None declared

Ethical approval: The study was approved by the Institutional Ethics Committee

\section{REFERENCES}

1. Marsh PD. Dental Biofilms, In: Lang N, Lindhe J(eds). Clinical Periodontology and Implant Dentistry $6^{\text {th }}$ Edn. Oxford U.K. John Wiley and Sons; 2015: 169.

2. Hioe K, Van der Weijden G. The effectiveness of self performed mechanical plaque control with triclosan containing dentifrices. Int J Dent Hyg. 2005;3:192-204. 
3. Gunsolley J. A meta- analysis of six-month studies of antiplaque and antigingivitis agents. J Am Dental Assoc. 2010;137:1649-57.

4. Paraskevas, Van der Weijden G. A review of the effects of Stannous Flouride on gingivitis. J Clin Periodontol. 2006;33:1-13.

5. Addy M, Moran J, Newcombe R. Meta-analyses of studies of $0.2 \%$ delmopinol mouthrinse as an adjunct to gingival health and plaque control measures. J Clin Periodontol. 2007;34:58-65.

6. Stoeken J, Paraskevas S, Van der Weijden G. The long term effect of a mouthrinse containing essential oils on dental plaque and gingivitis: a systematic review. J Periodontol. 2007;78:1218-28.

7. Gunsolley J. Clinical efficacy of anti-microbial mouthrinses. J Dent. 2010;38(1):6-10.

8. Sahrmann P, Puhan M, Attin T, Schmidlin P. Systematic review on the effect of rinsing with povidone-iodine during non-surgical periodontal therapy. J Periodontol Res. 2010;45:153-64.

9. Afennich F, Slot D, Hossainian N, Van der Weijden G. The effect of hexetidine mouthwash on prevention of plaque and gingival inflammation: A Systematic Review. Int J Dent Hyg. 2011;9:182-90.

10. Hossainian N, Slot D. Affenich F, Van der Weijden $\mathrm{G}$. The effect of hydrogen peroxide mouthwashes on the prevention of plaque and gingival inflammation: a systematic review. Int J Dent Hyg. 2011;9:171-81.

11. Jones C. Chlorhexidine: Is it still the gold standard? Perio 2000. 1997; 15:55-62.

12. Flotra L. Different modes of chlorhexidine application and related local side effects. J Periodontal Res Suppl. 1973;8:41-4.

13. Malhotra R, Grover V, Kapoor A, Saxena D. Comparison of the effectiveness of a commercially available herbal mouth rinse with chlorhexidine gluconate at the clinical and patient level. J Indian Soc Periodontol. 2011;15(4):349-52.

14. Amruthesh S. Dentistry and ayurveda III (basicsama, immunity, ojas, rasa, etiopathogenesis and prevention). Indian J Dent Res. 2007;18:112-9.

15. Jagdish L, Anand V, Kaviyarasan V. Effect of Triphala on dental biofilm. Indian J Sci Technol. 2009; 1:93-9.

16. Biswas N, Biswas A. Evaluation of some leaf dusts as grain protectant against rice weevil sitophlis oryzae (Linn). Environ Ecol. 2005;23(3):485-8.

17. Moghbel A, Farajzzadeh A, Aghel N, Agheli H, Raisi N. Toxicology letters. 2009;189(1):257.

18. Wolinsky L, Mania S, Nachnani S, Ling S. The inhibiting effect of aqueous Azadirachta indica (Neem) extract upon bacterial properties influencing in vitro plaque formation. $J$ Dent Res. 1996;75(2):816-22.

19. Nascimento G, Locatelli J, Freitas P, Silva G Antibacterial activity of plant extracts and phytochemicals on antibiotic-resistant bacteria. Braz J Microbiol. 2000;31:247-56.

20. Wynn RL. Aloe vera gel: Update for dentistry. Gen Dent. 2005;53:6-9.
21. Menezes S, Corderio L, Viana G. Punica granatum (pomegranate) extract is active against dental plaque. J Herb Pharmacother. 2006;6:79-92.

22. Nihad A. Evaluation of Antibacterial Activity of Cinnamomum zeylanicum Extract on Cariogenic Microorganisms of the Dental plaque. In-vitro Study and Scanning Electron Microscopic Assessment. MDJ. 2009;6(4):334-48.

23. Hussain T, Kandy. Antimicrobial effects of Citrus Sinensis Peel Extracts Against Periodontopathic Bacteria: An in vitro Study. Rocz Panstw Zakl Hig. 2015;66(2):173-8.

24. Zhenbin W, Zhongli P, Haile M, Griffith G. Extract of Phenolics from Peels. J Food Sci. 2015;5:17-25.

25. Schwalbe R, Steele-Moore L, Goodwin AC. Antimicrobial susceptibility testing protocols. New York. CRC Press; 2007.

26. Hudzicki J. 8 December 2009, posting date. KirbyBauer disk diffusion susceptibility test protocol. American Society for Microbiology, Washington, DC. http://www.microbelibrary.org/component/ resource/laboratory-test/3189-kirby-bauer-diskdiffusion-susceptibility-test-protocol.

27. Aboaba O, Efuwape B. Antibacterial Properties of Some Nigerian Species. Bio Res Comm. 2001;13:183-8.

28. Shimada T. Salivary proteins as a defense against dietary tannins. J Chem Ecol. 2006;32(6):1149-63.

29. Alams K, Skaug N, Ahmad I. An in vitro antimicrobial comparison of miswak extract with commercially available non-alcohol mouthrinses. Int J Dent Hyg. 2005;3(1):18-24.

30. Jardim E, Landucci L, Kidudsi Arafat O, Ranieri R, Ramos M., Ciesielski F, et al. Antimicrobial Activity of Six Plant Extracts from the Brazilian Savanna on Periodontal Pathogens. Int J Odontostomat. 2011;5(3):249-56.

31. Vahabi S, Najafi E, Alizadeh S. In-vitro antimicrobial effects of some herbal essences against oral pathogens. Planta Med. 2011;5(19):4870-8.

32. Madhuri S, Hegde A, Srilaxmi T, Prashith. Antimicrobial activity of Citrus sinensis and Citrus aurantium peel extracts. JPSI. 2014;3(4):366-9.

33. Lanciotti R, Gianotti A, Patrignani F, Belletti N, Guerzoni E, Gardini F. Use of natural aromacompounds to improve shelf-life and safety of minimally processed fruits. Trends Food Sci Tech. 2004; 15:201-8

34. Caccioni D, Guizzardi, M, Biondi, D, Renda A, Ruberto G. Relationship between volatile components of citrus fruit essential oils and antimicrobial action on Penicillium digitatum and Penicillium italicum. Int $\mathrm{J}$ Food Microbiol. 1998;43:73-9.

35. Dabbah R, Edwards M, Moats A. Antimicrobial action of some citrus fruit oils on selected food borne bacteria. J Appl Microbiol. 1970;19:27-31.

36. Lawal D, Bala J, Aliyu S, Huguma M. Phytochemical Screening and invitro Antibacterial 
Studies of the Ethanolic Extract of Citrus sinensis Peel against some Clinical Bacterial Isolates. IJIAS. 2013;2(2):138-45.

37. Vivek K, Nandin, Shashadhara S, Anitha S. AntiTyphoid activity of Aqueous extract of Fruit Peel Citrus sinensis. IJPRD. 2010;2(9):31.

38. Nisha S, Swedha A, Rahaman J. Antibacterial activity of citrus sinensis peel against enteric pathogens. IJPRBS. 2013;2(5):1-13.

39. Jeyaseelan E, Jashothan P. In vitro control of Staphylococcus aureus (NCTC 6571) and Escherichia coli (ATCC 25922) by Ricinus communis L. Asian Pac J Trop Biomed. 2012;2(9):717-21.
40. Lakhdar L, Farah A, Bajjou T, Rida S. In vitro Antibacterial Activity of Essentials Oils from Mentha pulegium, Citrus aurantium and Cymbopogon citratus on Virulent Strains of Aggregatibacter actinomycetemcomitans. IJPPR. 2015;6(4):1035-42.

Cite this article as: Mankar CD, Shah MU, Doshi YS, Bajaj M, Kevadia V, Vinod R. Evaluation of antimicrobial activity of orange peel extract against oral biofilm forming organisms: an in vitro microbial study and scanning electron microscopic assessment. Int J Basic Clin Pharmacol 2016;5:1917-23. 